Огляди літератури, оригінальні дослідження, погляд на проблему, випадок з практики, короткі повідомлення

удК 616.34-008.6-053.2

DOI 10.11603/1811-2471.2021.v.i3.12315

\title{
СУЧАСНИЙ ПОГЛЯД НА ФУНКЦІОНАЛЬНІ РОЗЛАДИ КИШЕЧНИКА У ДІТЕЙ: АНАЛІЗ ПЕДІАТРИЧНИХ КРИТЕРІЇВ РИМУ IV
}

\author{
๑О. М. Шульгай, А.-М. А. Шульгай \\ Тернопільський національний медичний університет імені І. Я. Горбачевського МОз України
}

\begin{abstract}
РЕЗЮМЕ. Актуальність проблеми функціональних гастроінтестинальних розладів (ФГР) не викликає сумнівів, оскільки переважна більшість патологічних станів, що виникають у дітей, мають саме функціональний характер.

Мета - проаналізувати Римські критерії IV та сформувати сучасний алгоритм діагностики функціональних розладів кишечника у дітей на етапі первинної медичної допомоги.

Матеріал і методи. У роботі застосовано інформаційний, бібліографічний та аналітичний методи у міжнародних медичних інформаційних електронних базах даних, що стосуються Римських критеріїв IV.

Результати. Причиною виникнення ФГР не $\epsilon$ біохімічні чи морфологічні порушення у роботі органів травлення, а переважно тимчасові розлади функціонування тих чи інших органів травної системи. У 2016 році були опубліковані Римські критерії IV, згідно з якими відбулося оновлення критеріїв на основі симптомів для діагностики дітей із ФГР. За даними оновленого перегляду для новонароджених та дітей раннього віку «правило трійки» для діагностики малюкових кольок було відмінене, при діагностиці функціонального запору було проведено розмежування між дітьми, які мають навички «охайності» (привчені до туалету), та тими, у кого ці навички відсутні. Для дітей та підлітків описані два нові ФГР - функціональна нудота та функціональне блювання, а також відмічено, що біль не повинен бути провідною скаргою при встановленні діагнозу функціональн ої диспепсії.

Висновки. Аналіз засад Римських критеріїв IV дозволяє правильно інтерпретувати результати обстеження дитини та скласти план медичного спостереження за педіатричним пацієнтом для покращення якості його життя.

КлючОВІ СлОВА: функціональні гастроінтестинальні розлади; кишечник; Римські критерії IV, діти.
\end{abstract}

Вступ. Лікар першого контакту у своїй практичній роботі щодня стикається із проблемами діагностики функціональних гастроінтестинальних розладів (ФГР) як у дорослих, так і у дітей. Під ФГР розуміють різноманітні порушення функції органів шлунково-кишкового тракту (ШКТ), що пов'язані зі зміною їх регуляції та супроводжуються комплексом гастроінтестинальних симптомів (залежно від віку) без структурних чи біохімічних порушень. Неоднозначність у трактуванні нозологій, що входять до групи ФГР, ускладнює діагностування даної проблеми у дитячому віці, призводить до проведення значної кількості непотрібних, іноді досить інвазивних обстежень, а також застосування нераціональної та бездоказової фармакотерапії [1-3].

Щодо діагностики ФГР у дітей раннього віку, то на сучасному етапі вона, насамперед, базується на скаргах батьків та наявному у дитини комплексі клінічних симптомів, тому переважно не потребує додаткових лабораторно-інструментальних обстежень $[1-3,5,6]$. Щодо лікування, то, згідно з думкою експертів Європейського товариства педіатричної гастроентерології, гепатології та нутриціології (ESPGHAN), ФГР у ранньому дитячому віці вважають тими клінічними станами, що минають самостійно, тому переважно не потребують призначення фармакотерапії $[1-3,7,8]$. Окрім того, у літературі існує думка, що ФГР - це патологія "виключення», тобто щоб встановити діагноз функціонального захворювання, особли- во у дитини раннього віку, необхідно виключати низку патологічних станів, таких як аномалії розвитку травного каналу, хвороби обміну речовин, інфекційні захворювання, хвороби центральної нервової системи, а також врахувати «симптоми тривоги», які $є$ свідченням більш складної, часто органічної патології. Але це більшою мірою стосується дорослих, оскільки частота виникнення у них хронічної патології із певними морфологічними змінами у внутрішніх органах $€$ значно вищою [1-3].

Враховуючи виникнення та різноманіття скарг, які виникають як прояв ФГР, мінливість симптомів та їх зникнення іноді без застосування медикаментів, стає зрозумілим актуальність подальшого вивчення даної групи захворювань, особливо у дітей. Уніфіковані підходи із позиції доказової медицини, використання світового досвіду, що знайшло своє відображення у Римських критеріях, дозволяє практичному лікарю розібратися у тактиці ведення пацієнтів із ФГР [4]. Однією із проблем застосування Римських критеріїв у дітей, особливо раннього віку, є достовірність і деталізація скарг та історії хвороби малюка. Крім того, залишається дискутабельним, чи всі діагнози, що були включені до Римських критріїв IV, $\epsilon$ насправді клінічними розладами та можуть бути встановлені лише за допомогою розпитування та об'єктивного клінічного обстеження, а також чи всі вони пов'язані саме із проблемами шлунковокишкового тракту [5-8]. 
Огляди літератури, оригінальні дослідження, погляд на проблему, випадок з практики, короткі повідомлення

Переглянуті та оновлені у 2016 році Римські критерії IV пропонують новий алгоритм ведення дітей із ФГР та нові підходи до визначення даних порушень, де їх визначають як «розлад взаємодії кишка - головний мозок» (disorders of gut-brain interaction). Вісь «кишка - головний мозок» $€$ нервово-анатомічним утворенням, в якому різноманітні психосоціальні чинники впливають на функціонування травного каналу, і навпаки. Між головним мозком і кишечником існує складна система взаємозалежних зв'язків, яка передає інформацію від емоційних і когнітивних центрів головного мозку, що сприяють думкам, почуттям, спогадам, регуляції болю, за допомогою нейромедіаторів для периферійного функціонування травного каналу, і навпаки $[2,4]$. Сучасні Римські критерії функціональних розладів травного каналу базуються переважно на оцінці симптомів та врахуванні анатомії певного органа, що є суттєвою перевагою для застосування їх у практиці, оскільки дозволяє швидше зорієнтуватися у попередньому діагнозі. Механізми формування ФГР різноманітні, вони визначаються не лише анатомо-фізіологічними особливостями певних органів, а й розладами вегетативної і гуморальної регуляції організму дитини. Основними причинами, що не дають можливості вчасно встановити діагноз ФГР та виробити тактику ведення таких пацієнтів, $\epsilon$ відсутність чіткого розуміння механізму їх виникнення, недостатня обізнаність лікарів першого контакту з критеріями діагностики та сучасними можливостями методів дослідження [2, 3, 10].

Мета - аналіз Римських педіатричних критеріїв IV перегляду для більш широкого застосування їх у педіатричній практиці.

Матеріал і методи дослідження. У роботі застосовано інформаційний, бібліографічний та аналітичний методи у міжнародних медичних інформаційних електронних базах даних, що стосуються Римських критеріїв IV.

Результати й обговорення. Згідно з Римськими критеріями IV, ФГР у дітей різного віку поділені на дві групи: G (педіатричні функціональні розлади, що спостерігаються у новонароджених і малюків) та Н (педіатричні функціональні розлади, що трапляються у дітей та підлітків), причому за основу даного розподілу взяті базові скарги дітей або їх батьків $[1,9,11,12]$. До групи G (новонароджені та діти віком від 0 до 3 років) віднесені такі ФГР: малюкова регургітація (G1), синдром румінації у немовлят (G2), синдром циклічного блювання (G3), малюкові кольки (G4), функціональна діарея (G5), малюкова дисшезія (G6), функціональний запор (G7). До групи Н (діти віком від 4 до 18 років) віднесені: функціональні нудота і блювання (Н1) та різновиди даного функціонального стану, такі як синдром циклічного блювання (Н1a), функціональна нудота та функціональне блювання (H1b), синдром румінації (H1c), аерофагія (H1d); функціональні абдомінальні больові розлади (H2), до яких включені функціональна диспепсія (H2a), синдром подразненої кишки (H2b), абдомінальна мігрень (Н2c) та функціональний органонеспецифічний абдомінальний біль (H2d); а також функціональні розлади дефекації (Н3), куди увійшли функціональний запор (Н3а) та неретенційне нетримання калу (Н3b). На рисунку 1 зображені час появи та поєднання ФГР у дітей різного віку $[1,11,12]$.

Зупинимося детальніше на тих ФГР, які стосуються патології кишечника у дітей різного віку. Досить часто у дітей першого року (особливо від 2-3 тижнів до 4-6 місяців життя) зустрічаєтся діагноз малюкових кольок. У Римських критеріях IV немає «правила трійки» (плач більше 3 годин на день, тривалістю більше 3 днів на тиждень, частотою більше 3 тижнів), оскільки чітко відслідкувати та зафіксувати ці критерії неможливо [15, 16]. Критеріями малюкової кольки $\epsilon$ наявність симптомів у дитини віком до 5 місяців, які проявляються тривалими епізодами плачу/неспокою/ дратівливості, виникають та зникають без явної причини, не можуть бути передбачені або усунуті вихователем, при відсутні проявів затримки розвитку дитини чи іншого захворювання. При цьому термін «пароксизм» (або напад) не враховується, оскільки немає доказів, що саме початок епізоду малюкової кольки з'являється більш різко чи відрізняється звучанням, порівняно зі звичайними епізодами плачу у дитини. Батьки повинні вести щоденник поведінки дитини протягом 24 годин, що6 зафіксувати та підтвердити епізоди плачу та метушливості протягом 3 і більше годин на день впродовж 3 днів і більше на попередньому тижні, які при цьому не супроводжуються порушеннями розвитку. Критерії підтвердження діагнозу малюкових кольок зосереджені на факторах, які викликають страждання у малюка і батьків, тобто тривалий і незрозумілий характер плачу та зміни поведінки. Так, ці симптоми можуть призвести до занепокоєння батьків, багато з них консультують своїх малюків у лікаря, хоча за походженням зв'язок із проблемами кишечника $є$ сумнівним, оскільки теорій походження малюкових кольок $\epsilon$ безліч $[15,16]$.

До функціональних розладів дефекації у дітей раннього віку належить також функціональна діарея, основними проявами якої, згідно з Римськими критеріями IV, $є$ вік дитини від 6 до 36 місяців життя, безболісна дефекація значною кількістю несформованих випорожнень не менше 4 разів на добу, відсутність змін частоти випорожнень під час сну, тривалість цих змін від 4 тижнів і довше, задо- 
Огляди літератури, оригінальні дослідження, погляд на проблему, випадок з практики, короткі повідомлення

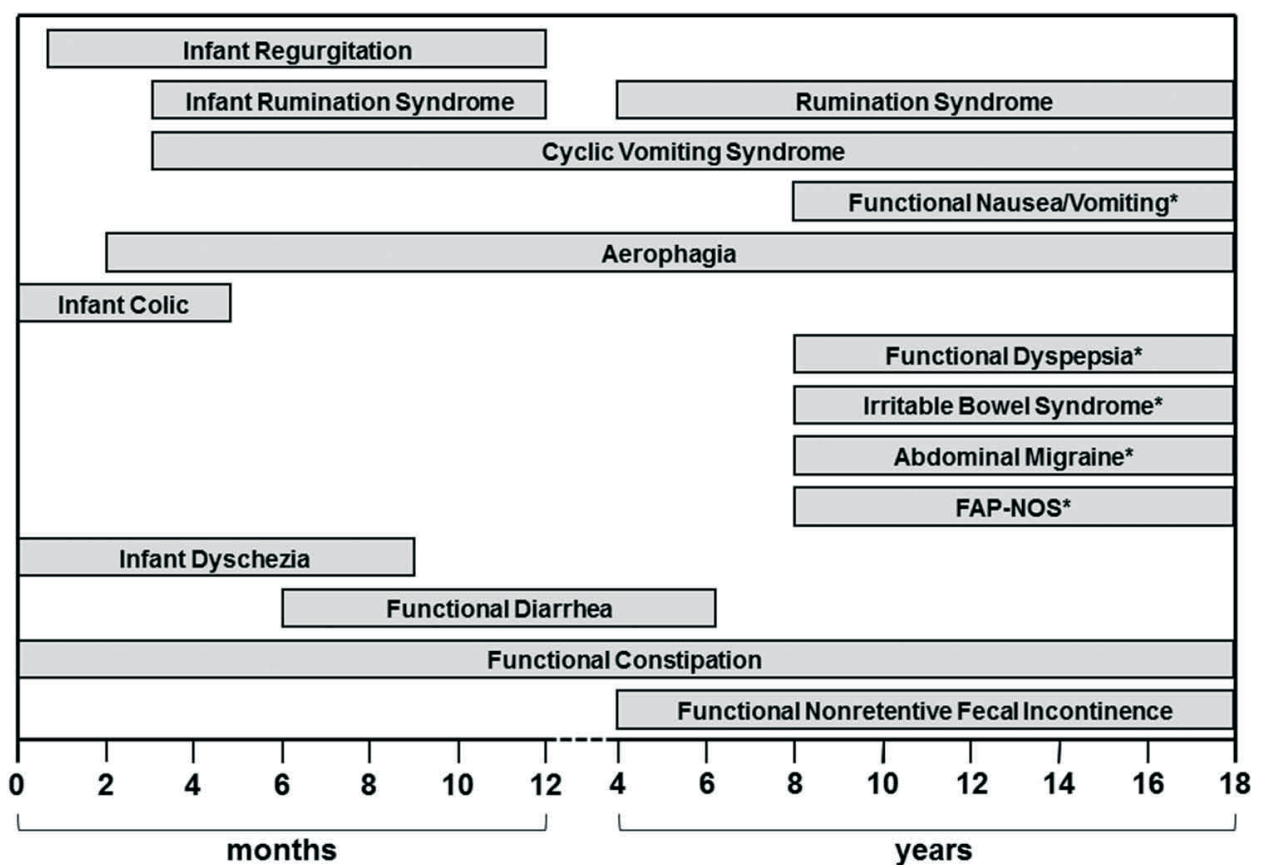

Примітка. * - діагноз даного розладу може бути недостовірним нижче зазначеного віку.

Рис. 1. Функціональні гастроінтестинальні розлади, зазначені у Римських критеріях IV, та вік, у якому вони можуть мати місце.

вільний стан загального розвитку малюка при достатньому білково-енергетичному балансі [7].

у частини дітей перших 2-3 місяців життя з'являються прояви малюкової дисшезії, діагностичними критеріями якої (згідно з Римськими критеріями IV) $є$ такі: для здорових дітей до досягнення ними 9-місячного віку характерні такі прояви дисшезії як напруження і плач перед дефекацією, пов'язані не лише із успішним, але й невдалим проходженням випорожнення.

Понад третина дітей раннього віку вже на першому році життя мають проблему функціонального запору. Ця патологія у дітей раннього віку пов'язана із порушенням функцій кишечника, проявляється збільшенням інтервалів між дефекаціями (враховуючи індивідуальну норму) або регулярним неповним випорожненням кишечника, але за відсутності будь-якої органічної патології $[13,17,18]$. Згідно із Римськими критеріями IV, функціональний запор діагностують за наявності у дітей до 4-річного віку не менше двох із наступних ознак протягом 1 місяця: 1) не більше 2 дефекацій за тиждень; 2) нетримання калу після набуття дитиною гігієнічних навичок (не менше 1 разу на тиждень), при цьому дитина $\epsilon$ добре підготовленою до туалету та привчена до горщика; 3) ознаки затримки дефекації та вказівки на випорожнення каловими масами великого діаметра в анамнезі; 4) ознаки болючих дефекацій або наявність твердих випорожнень (навіть при регулярних випорожненнях); 5) наявність значної кіль- кості фекальних мас у прямій кишці перед початком дефекації. Окрім перерахованих ознак, можуть бути наявні супутні симптоми, а саме дратівливість, зниження апетиту та/або раннє насичення, які минають відразу після відходження значної кількості фекальних мас.

При діагностиці ФГР у дітей раннього віку, що супроводжуються запорами, необхідно враховувати «симптоми тривоги», які можуть свідчити про наявність органічної патології [13]:

- ранній початок запору (у віці до 1 місяця);

- виділення меконію більше ніж через 48 годин після народження у доношеного новонародженого або його відсутність;

- обтяжений сімейний анамнез щодо хвороби Гіршпрунга;

- стрічкоподібні або дуже бідні випорожнення;

- кров у калі за відсутності анальних тріщин;

- затримка фізичного і нервово-психічного розвитку дитини;

- лихоманка;

- виразне здуття живота;

- періанальна фістула та рубці у ділянці анального отвору;

- зниження а6о відсутність м'язової сили нижніх кінцівок/тонусу/рефлексів, відсутність анального або кремастерного рефлексів;

- жмут волосся над остистим відростком хребця та западина у ділянці крижів (непряма ознака spina bifida); 
Огляди літератури, оригінальні дослідження, погляд на проблему, випадок з практики, короткі повідомлення

- сильний страх під час огляду ануса або несприйняття горщика.

Чим менший вік дитини із запорами, тим вищим є ризик наявності анатомічної аномалії або органічного ураження. За відсутності наведених симптомів використання додаткових методів обстеження не рекомендоване $[10,17,18]$.

Істотних змін щодо встановлення діагнозів функціонального запору чи функціонального неретенційного нетримання калу для дітей старшого віку і підлітків у Римських критеріях IV немає, оскільки провідні критерії не відрізняються від таких у новонароджених та дітей раннього віку. Для обох цих функціональних розладів змінився лише час, за який відбувається оцінка симптомів, тобто 1 місяць, а не 2, оскільки триваліший час відтерміновує початок лікування дитини із ФГР, а також не узгоджується із критеріями подібних ФГР у новонароджених та дітей раннього віку.

Отже, критеріями встановлення діагнозу неретенційного нетримання калу $є$ поява таких симптомів у дитини старше 4 років (тривалістю не менше 1 місяця): 1) дефекація у місцях, що не відповідають соціокультурному контексту; 2) немає доказів затримки калу; 3) після відповідного медичного обстеження нетримання калу не пояснюють інші порушення стану здоров'я [19].

Одним із найчастіших ФГР кишечника у дітей старшого віку і підлітків є синдром подразненого кишечника (СПК). СПК у дітей, як і в дорослих, поділяється на підтипи, що відображають переважну консистенцію випорожнень: СПК із переважанням запору, СПК із переважанням діареї, СПК із чергуванням запорів та діареї та неуточнений СПК. Унаслідок перенесеної кишкової інфекції (гострого інфекційного гастроентериту) відбувається підвищення запальних цитокінів слизової, що може бути причиною окремої форми, описаної у літературі - постінфекційного СПК $[20,21]$.

Провідними скаргами при СПК у дітей є: діарея, запор, діарея, що чергується із запорами, метеоризм, здуття живота, слиз у випорожненнях, блювання, нудота, втрата маси (у частини дітей), терміновість при дефекації, відчуття неповного спорожнення після акту дефекації. Щоб встановити діагноз СПК, лікар першого контакту повинен детально розпитати дитину щодо симптомів та клінічно обстежити, щоб виключити більш серйозні проблеми чи захворювання. СПК не $\epsilon$ хворобою, при якій відбуваються морфологічні зміни у кишечнику - це синдром або комплекс симптомів, які виникають практично одночасно та значно погіршують якість життя. Виникнення СПК у дітей пов'язують із вісцеральною гіперчутливістю не лише кишечника, а й шлунка, яка виникає внаслідок психологічного дистресу (тривога, депресія, імпульсивність, гнів) [21].

За допомогою Римських критеріїв IV було з'ясовано, як відрізнити функціональний запор та СПК із запорами. Якщо дитина страждає запорами та болем у животі, пов'язаними із дефекацією або зміною частоти чи форми випорожнень, то цій дитині необхідно спочатку призначити лікування для ліквідації запорів. Якщо, незважаючи на успіх лікування запорів, біль у животі все ж зберігається, то такій дитині встановлюють діагноз СПК із запорами.

Згідно з Римськими критеріями IV, діагноз СПК встановлюють тоді, коли наявний рецидивний біль у животі не менше 1 дня на тиждень впродовж останніх 3 місяців (за 6 місяців до встановлення діагнозу), який поєднується із двома або більше наступними даними: зв'язок із дефекацією, асоціація зі зміною частоти випорожнення, асоціація зі зміною форми випорожнення [21].

Згідно з даними критеріями з них виключене поняття «дискомфорт», оскільки воно $є$ некоректним, а головним критерієм $є$ біль, який не завжди пов'язаний зі змінами випорожнень та не завжди зменшується чи зникає після дефекації. При поділі СПК на підтипи рекомендовано враховувати лише пропорції змінених випорожнень (грудкуваті/тверді або неоформлені/рідкі), а не всі випорожнення (включно з нормальними).

Досить важливим для встановлення діагнозу СПК $є$ відсутність характерних «симптомів тривоги», таких як невмотивована втрата маси тіла; наявність симптоматики в нічний час; переважання постійного інтенсивного болю в животі як провідного, а іноді і єдиного симптому ураження шлунково-кишкового тракту; лихоманка; збільшення паренхіматозних органів (печінки, селезінки); лейкоцитоз, анемія, збільшення ШОЕ; домішки крові у випорожненнях. Наявність хоча 6 одного з перерахованих «симптомів тривоги» робить діагноз СПК сумнівним та визначає необхідність подальшого ретельного обстеження пацієнта [20, 21].

Згідно з засадами Римських критеріїв IV рекомендується такий діагностичний алгоритм при виявленні дитини із підозрою на СПК (рис. 2).

Для встановлення діагнозу функціонального запору в дітей старшого віку, згідно з Римськими критеріями IV, необхідно у дитини після 4 років мати дві або більше із наступних ознак, що спостерігаються не рідше 1 разу на тиждень протягом мінімум 1 місяця (при відсутності критеріїв для діагностики СПК): 1) 2 або менше дефекацій у туалеті на тиждень; 2) хоча 61 епізод нетримання калу на тиждень; 3) надмірна вольова затримка випорожнення; 4) дані з історії хвороби про болючі або тверді випорожнення; 5) наявність вели- 
Огляди літератури, оригінальні дослідження, погляд на проблему, випадок з практики, короткі повідомлення

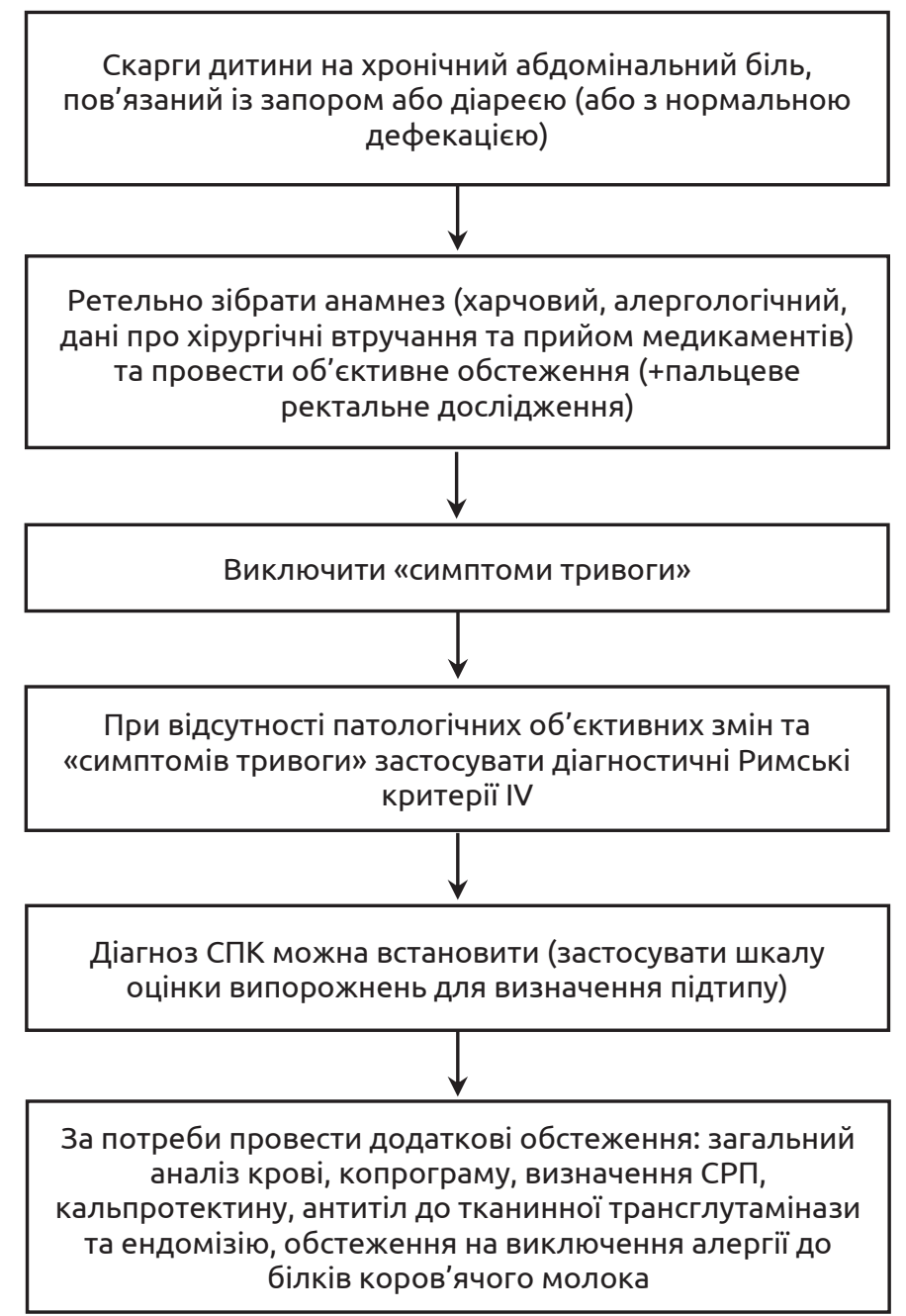

Рис. 2. Діагностичний алгоритм для встановлення діагнозу СПК у педіатричного пацієнта.

кої кількості калових мас у прямій кишці; 6) інформація про випорожнення значного діаметра, які складно видалити з унітаза; 7) після відповідної оцінки симптомів їх неможливо пояснити іншим захворюванням [22-24].

Проведення лабораторних досліджень чи рутинного рентгенологічного обстеження дітям із запорами при відсутності «симптомів тривоги» не рекомендуються. Якщо необхідно виключити хворобу Гіршпрунга, повинна бути проведена біопсія прямої кишки, що $\epsilon$ «золотим стандартом». Клізму з барієм не слід використовувати як початковий етап діагностики для оцінки функціонального запору.

Рекомендації щодо лікування ФГР у дітей із доведеною ефективністю досить обмежені, особливо для пацієнтів раннього віку. Лікування неретенційного нетримання калу $\epsilon$ досить проблемним, оскільки при даному ФГР рекомендовані насамперед психологічне консультування з активною участю батьків та поведінкова терапія [19].
Лікування СПК і функціонального запору повинно включати корекцію харчування (шляхом введення до раціону дитини більше рідини і клітковини), поведінкову терапію (привчання кишечника для регулярного спорожнення у певний час протягом дня, ведення щоденника випорожнень, винагороди за успішну дефекцію, усунення фобії туалету). Фармакологічне лікування складається з двох етапів: ректальних або пероральних послаблювальних, причому препаратам поліетиленгліколю необхідно надавати перевагу у терапії дітей із закрепами. Однак, дітям із закрепами проносні препарати слід застосовувати з обережністю, лише під контролем лікаря, оскільки це може призвести до звикання та ускладнити проблему [21-24].

Висновки. Римські діагностичні критерії IV ФГР для немовлят і малюків, для дітей та підлітків були відкореговані згідно з проведеними дослідженнями щодо причин та механізмів їх виникнення. Ці критерії перегляду 2016 року змінили акценти, згідно з якими практичний лікар повинен 


\section{Огляди літератури, оригінальні дослідження, погляд на проблему, випадок з практики, короткі повідомлення}

обстежувати та лікувати дітей. Із визначенням функціональної нудоти та функціонального блювання як окремих розладів, значних змін у діагностиці малюкових кольок, абдомінальної мігрені та функціональної диспепсії, поширеність даних розладів та симптоматика пацієнтів змінилися, що вимагає проведення нових досліджень із залученням груп педіатричних пацієнтів різного віку. Завдяки запропонованим критеріям було покращено клінічну допомогу дітям та якість їх життя. Окрім цього, даних міжнародних критеріїв необхідно дотримуватися у майбутніх наукових медичних дослідженнях із метою встановлення їх достовірності, що дозволить коректно порівнювати отримані результати. Створення конкретних критеріїв для ФГР $є$ надзвичайно важливим для встановлення адекватних діагнозів при першому контакті із дитиною, що дозволить пацієнтам і сім'ї зрозуміти проблему та допоможе запобігти непотрібному обстеженню та сприятиме обмеженню витрат на збереження здоров'я.

\section{ЛІТЕРАТУРА}

1. Childhood Functional Gastrointestinal Disorders: Neonate/Toddler / M. A. Benninga, C. Faure, P. E. Hyman [et al.] // Gastroenterology. - 2016. - No. 150. - P. 14431455. https://doi.org/10.1053/j.gastro.2016.02.016

2. Drossman D. A. Rome IV-Functional GI disorders: disorders of gut-brin interaction / D. A. Drossman, W. L. Halster // Gastroenterology. - 2016. - No. 150 (6). - P. 12571261. https://doi.org/10.1053/j.gastro.2016.03.035

3. Drossman D. A. Functional gastrointestinal disorders: history, pathophysiology, clinical features and Rome IV / D. A. Drossman // Gastroenterology. - 2016. - No. 150. P. 1262-1279. https://doi.org/10.1053/j.gastro.2016.02.032

4. Tack J. What's new in Rome IV? / J. Tack, D. A. Drossman // Neurogastroenterol. Motil. - 2017. No. 29 (9). https://doi.org/10.1111/nmo.13053

5. Захарова И. Н. Функциональные гастроинтестинальные расстройства у детей раннего возраста: критерии диагностики и подходы к диетотерапии / И. Н. Захарова, Н. Г. Сугян, И. В. Бережная // Российский вестник перинатологии и педиатрии. - 2018. - № 63 (1). - С. 113121. https://doi.org/10.21508/1027-4065-2018-63-1-113-121

6. Gastrointestinal symptoms in infancy: a population-based prospective study / G. Iacono, R. Merolla, D. D'Amico [et al.] // Dig. Liver Dis. - 2005. - No. 37 (6). P. 432-438. https://doi.org/10.1016/j.dld.2005.01.009

7. Дубровская М. И. Функциональные нарушения желудочно-кишечного тракта у детей раннего возраста как зеркало нарушений отношений в диаде мать дитя / М. И. Дубровская, Е. И. Грязнова // Лечащий врач. - 2019. - № 6. - С. 19-23. https://doi.org/10.26295/ OS.2019.54.11.004

8. Бєлоусова О. Ю. Функціональні гастроінтестинальні розлади в дітей раннього віку: лікувати, спостерігати чи корегувати / О. Ю. Бєлоусова, Л. В. Казарян //
Перспективи подальших досліджень. Надалі необхідно враховувати, що патофізіологічні механізми у більшості дітей раннього віку із ФГР $\epsilon$ недостатньо вивченими, тому необхідні багатоцентрові проспективні дослідження значної кількості дітей. Протягом кількох наступних років очікуються подальші обстеження для поглиблення знань про розвиток ФГР у дітей, що надихнуть на оновлення Римських критеріїв. Краще розуміння причин і механізмів виникнення ФГР у дітей може привести до визначення нових підтипів, а це вплине на діагностику та лікування їх у майбутньому. Крім того, сучасні дослідження можуть мати вплив на діагностику та лікування ФГР у дітей, оскільки будуть випробувані нові фармакологічні і нефармакологічні засоби, наприклад, терапія, спрямована на вісь «кишечник - головний мозок» (гіпнотерапія, самогіпноз, йога) та терапія з метою впливу на мікробіоту кишечника (пре- та пробіотики, синбіотики, фекальна трансплантація).

Здоровье ребенка. - 2020. - No. 15 (1). - С. 24-29. http://dx.doi.org/10.22141/2224-0551.15.1.2020.196754

9. Педіатричні критерії Риму IV: зміни та порівняння з Римськими критеріями III / С. І. Єсипова, Б. Я. Дмитришин, О. А. Бовкун, О. А. Дмитришин // Семейная медицина. - 2018. - № 1 (75). - 20-23.

10. Childhood functional gastrointestinal disorders: neonate/toddler / P. E. Hyman, P. J. Milla, M. A. Benninga [et al.] Taminiau // Gastroenterology. - 2006. - No. 130. - P. 15191526. https://doi.org/10.1053/j.gastro.2005.11.065

11. The pediatric Rome IV criteria: what's new? / I. J. N. Koppen, S. Nurko, M. Saps [et al.] // Journal Expert Review of Gastroenterology \& Hepatology. - 2017. No. 11. - P. 193-201. https://doi.org/10.1080/17474124.20 17.1282820

12. Zeevenhooven J. The New Rome IV Criteria for Functional Gastrointestinal Disorders in Infants and Toddlers / J. Zeevenhooven, I. J. N. Koppen, M. A. Benninga // Pediatr. Gastroenterol. Hepatol. Nutr. - 2017. - No. 20(1). P. 1-13. https://doi.org/10.5223/pghn.2017.20.1.1

13. Шадрін О. Г. Сучасні підходи до діагностики та лікування функціонального запору у дітей раннього віку / О. Г. Шадрін // Современная педиатрия. - 2017. - № 5 (85). - P. 126-130. https://doi.org/10.15574/SP.2017.85.126 14. Childhood Functional Gastrointestinal Disorders: Child / Adolescent / J. S. Hyams, C. Di Lorenzo, M. Saps [et al.] // Gastroenterology. - 2016. - No. 130 (5). - P. 14561468 https://dx.doi.org/10.1053 \%2Fj.gastro.2005.08.063

15. Paroxysmal fussing in infancy, sometimes called colic / M. A. Wessel, J. C. Cobb, E. B. Jackson [et al.] // Pediatrics. - 1954. - No. 14. - P. 421-435.

16. Kheir A. E. M. Infantile colic, facts and fiction / A. E. M. Kheir // Ital. J. Pediatr. - 2012. - No. 38. - P. 34. https://doi.org/10.1186/1824-7288-38-34 
Огляди літератури, оригінальні дослідження, погляд на проблему, випадок з практики, короткі повідомлення

17. Белоусова О. Ю. Современный взгляд на функциональные запоры у детей раннего возраста: особенности вскармливания и принципы немедикаментозной коррекции / О. Ю. Белоусова // Здоровье ребенка. 2015. - № 1. - C. 140-148. https://doi.org/10.22141/ 2224-0551.14.0.2019.165514

18. Белоусова О. Ю. Функциональный запор у детей раннего возраста в свете Римских критериев IV пересмотра. Международные рекомендации / О. Ю. Белоусова // Здоровье ребенка. - 2019. - № 14 (1). - С. 16-24. https://doi.org/10.22141/2224-0551.14.0.2019.165514

19. Voskuijl W. P. Longitudinal follow-up of children with functional nonretentive fecal incontinence / W. P. Voskuijl, J. B. Reitsma, R. vanGinkel // Clin. Gastroenterol. Hepatol. - 2006. - No. 4. - P. 67-72. https://doi. org/10.1053/j.gastro.2016.02.015

20. Post-infectious functional gastrointestinal disorders in children / M. Saps, L. Pensabene, L. Di Martino [et al.] // J. Pediatr. - 2008. - No. 152 (6). - P. 812-816. https:// doi.org/10.1016/j.jpeds.2007.11.042

\section{REFERENCES}

1. Benninga, M.A., Faure, C. \& Nurko, S. (2016). Childhood Functional Gastrointestinal Disorders: Neonate/Toddler Gastroenterology. 150, 1443-1455. https://doi. org/10.1053/j.gastro.2016.02.016

2. Drossman, D.A. \& Haster, W.L. (2016). Rome IVFunctional GI disorders: disorders of gut-brin interaction. Gastroenterology, 150(6), 1257-1261. https://doi.org/ 10.1053/j.gastro.2016.03.035

3. Drossman, D.A. (2016). Functional gastrointestinal disorders: history, pathophysiology, clinical features and Rome IV. Gastroenterology, 150. 1262-1279. https:// doi.org/10.1053/j.gastro.2016.02.032

4. Tack, J. \& Drossman, D.A. (2017). What's new in Rome IV? Neurogastroenterol. Motil, Sep; 29(9). https:// doi.org/10.1111/nmo.13053

5. Zakharova, I.N., Sugyan, N.G., \& Berezhnaya, I.V. (2018). Funktsionalnyie gastrointestinalnyie rasstroystva u detei ranniego vozrasta: kriterii diagnostiki i podhody k dietoterapii [Functional gastrointestinal disorders in the infants: diagnostics criteria and approaches to the dietary therapy]. Rossiyskiy Vestnik Perinatologii i Pediatrii-Russian Bulletin of Perinatology and Pediatrics, 63(1), 113-121. [In Russian] https://doi.org/10.21508/1027-4065-2018-63-1-113-121

6. lacono, G., Merolla, R. \& Carroccio, A. (2005). Paediatric Study Group on Gastrointestinal Symptoms in Infancy. Gastrointestinal symptoms in infancy: a populationbased prospective study. Dig. Liver Dis., 37(6), 432-438 https://doi.org/10.1016/j.dld.2005.01.009

7. Dubrovskaya, M.I. \& Griaznova, E.I. (2019). Funksionalnye narusheniya jeludochno-kishechnogo trakta $v$ diade mat - ditya [Functional disorders of the gastrointestinal tract in young children as a mirror of disorders in relationships in the mother-child dyad]. Lechashchiy vrach - Attending Doctor, 6, 19-23 [in Russian]. https://doi.org/10.26295/ OS.2019.54.11.004

8. Belousova, O.Yu. \& Kazarian, L.V. (2020). Funktsionalni hatsrointestynalni rozlady v ditei rannioho viku: liku-
21. Devanarayana N. M. Irritable bowel syndrome in children: Current knowledge, challenges and opportunities / N. M. Devanarayana, S. Rajindrajith // World J. Gastroenterol. - 2018. - No. 24 (21). - P. 2211-2235. https:// doi.org/10.3748/wjg.v24.i21.2211

11. Evaluation and treatment of functional constipation in infants and children: evidence-based recommendations from ESPGHAN and NASPGHAN / M. M. Tabbers, C. DiLorenzo, M. Y. Berger [et al.] // Journal of Pediatric Gastroenterology and Nutrition. - 2014. - No. 58. - P. 258274. https://doi.org/10.1097/MPG.0000000000000266

12. Loening-Baucke V. Constipation in early childhood: patient characteristics, treatment, and long-term follow up / V. Loening-Baucke // Gut. - 1993. - No. 34. - P. 14001404. https://dx.doi.org/10.1136\%2Fgut.34.10.1400

24. Functional constipation in children: challenges and solutions / E. I. Levy, R. Lemmens, Y. Vandenplas, T. Devreker // Pediatric Health Med. Ther. - 2017. - No. 8. - P. 19-27. https://doi.org/10.2147/PHMT.S110940 vaty, sposterihaty chy korehuvaty [Functional gastrointestinal disorders in young children: treat, observe or correct?]. Zdorovye rebenka-Health of a Child, 15 (1), 24-29. [in Ukrainian]. http://dx.doi.org/10.22141/2224-0551.15.1.2020.196754

9. Yesipova, S.I., Dmytryshyn, B.Ya. \& Dmytryshyn, O.A. (2018). Pediatrichni kriteriyi Rimu IV: zmini ta porivnyannya z Rimskimi kriteriyami III. Semejnaya medycyna-Family Medicine, 1(75), 20-23 [in Russian].

10. Hyman, P.E., Milla, P.J. \& Taminiau, J. (2006). Childhood functional gastrointestinal disorders: neonate/ toddler. Gastroenterology, 130, 1519-1526. https://doi.org/ 10.1053/j.gastro.2005.11.065

11. Koppen, I.J.N., Nurko, S. \& Benninga, M.A. (2017). The pediatric Rome IV criteria: what's new? Journal Expert Review of Gastroenterology \& Hepatology, 11,193-201. https://doi.org/10.1080/17474124.2017.1282820

12. Zeevenhooven, J., Koppen, I.J.N. \& Benninga, M.A. (2017). The New Rome IV Criteria for Functional Gastrointestinal Disorders in Infants and Toddlers. Pediatr. Gastroenterol Hepatol. Nutr., 20(1), 1-13. https://doi.org/10.5223/ pghn.2017.20.1.1

13. Shadrin, O.G. (2017). Suchasni pidhody do diagnostyky ta likuvannya funkcionalnoho zaporu u ditej rannioho viku [Modern approaches to diagnosis and treatment of functional constipation in young children]. Sovremennaya pediatriya - Modern Pediatry, 5(85), 126-130. [in Ukrainian]. https://doi.org/10.15574/SP.2017.85.126

14. Hyams, J.S., DiLorenzo, C., \& van Tilburg M. (2016). Childhood Functional Gastrointestinal Disorders: Child/ Adolescent. Gastroenterology, 130 (5), 1456-1468. https:// dx.doi.org/10.1053 \%2Fj.gastro.2005.08.063

15. Wessel, M.A., Cobb, J.C., \& Detwiler, A.C. (1954). Paroxysmal fussing in infancy, sometimes called colic. Pediatrics, 14, 421-435.

16. Kheir, A.E.M. (2012). Infantile colic, facts and fiction. Ital. J. Pediatr., Jul 23; 38, 34. https://doi.org/ 10.1186/1824-7288-38-34 
Огляди літератури, оригінальні дослідження, погляд на проблему, випадок з практики, короткі повідомлення

17. Belousova, O.Yu. (2015). Sovremennyy vzglyad na funktsionalnye zapory u detey rannego vozrasta: printsipy nemedikamentoznoy korrektsii [Modern view on functional constipation in young children: principles of nondrug correction]. Zdorovye rebenka - Child Health, 1(60), 140-153 [in Russian]. https://doi.org/10.22141/22240551.14.0.2019.165514

18. Belousova, O.Yu. (2019). Funkstionalnyy zapor u detey rannego vozrasta v svete Rimskikh kriteriiv IV peresmotra. Mezhdunarodnye rekomendatsii [Functional constipation in young children in the light of the Rome IV revision criteria. International recommendations]. Zdorovye rebenka - Child Health, 14 (1), 16-24. [in Russian]. https:// doi.org/10.22141/2224-0551.14.0.2019.165514

19. Voskuijl, W.P., Reitsma, J.B. \& van Ginkel, R. (2006). Longitudinal follow-up of children with functional nonretentive fecal incontinence. Clin. Gastroenterol. Hepatol., 4, 67-72. https://doi.org/10.1053/j.gastro.2016.02.015

20. Saps, M., Pensabene, L. \& Lorenzo, C. (2008). Postinfectious functional gastrointestinal disorders in children.
J. Pediatr., 152(6), 812-816. https://doi.org/10.1016/j. jpeds.2007.11.042

21. Devanarayana, N.M. \& Rajindrajith, S. (2018). Irritable bowel syndrome in children: Current knowledge, challenges and opportunities. World J. Gastroenterol, 24(21), 2211-2235. https://doi.org/10.3748/wjg.v24.i21.2211

22. Tabbers, M.M., DiLorenzo, C., \& Benninga, M.A. (2014). Evaluation and treatment of functional constipation in infants and children: evidence-based recommendations from ESPGHAN and NASPGHAN. Journal of Pediatric Gastroenterology and Nutrition, 58, 258-274. https://doi. org/10.1097/MPG.0000000000000266

23. Loening-Baucke, V. (1993). Constipation in early childhood: patient characteristics, treatment, and longterm follow up. Gut, 34, 1400-1404. https://dx.doi. org/10.1136\%2Fgut.34.10.1400

24. Levy, E.I., Lemmens, R. \& Devreker, T. (2017). Functional constipation in children: challenges and solutions. Pediatric Health Med. Ther., 8, 19-27. https://doi. org/10.2147/PHMT.S110940

\section{A MODERN VIEW ON FUNCTIONAL INTESTINAL DISORDERS IN CHILDREN: ANALYSIS OF PEDIATRIC ROME IV CRITERIA}

\section{@o. M. Shulhai, A.-M. A. Shulhai \\ I. Horbachevsky Ternopil National Medical University}

SUMMARY. The urgency of the problem of functional gastrointestinal disorders (FGIDs) is beyond doubt, as most of pathological conditions that occur in children have a functional etiology.

The aim - to analyze the Rome IV criteria and form a modern diagnostic algorithm of the functional bowel disorders for children at the stage of primary care.

Material and Methods. The prospective and retrospective data collection, synthesis, data discussion, and peer-review and analytical methods from the international medical electronic databases concerning the Roman criteria IV were accomplished in the work.

Results. The cause of FGIDs is not biochemical or morphological disorders of the digestive system, but mainly temporary disorders of the functioning of some organs in the digestive system. In 2016, the Rome IV Criteria were published, according to which for children there were update FGIDs criteria based on symptoms. According to revised review for newborns and young children, the "rule of three" for colic diagnosing was abolished, in children with functional constipation, a distinction was made between children who have the skills of "neatness" (toilet trained) and those who have not. For children and adolescents, two new FGIDs have been described - functional nausea and functional vomiting, and it has been noted that pain should not be the main complaint in the functional dyspepsia diagnosis.

Conclusions. The analysis of the Rome IV criteria provides to correctly interpret data of child's examination and make a plan for a pediatric patient of medical treatment and observation to improve the quality of patient life.

KEY WORDS: functional gastrointestinal disorders; FGIDs; intestine; Rome IV criteria; children. 